\title{
The Opportunity of Indonesia to Accelerate the Utilization of Fly Ash and Bottom Ash Coal Waste Through International Cooperation
}

\author{
Melinda Putri Aryanti \\ Communication Science Department \\ Lampung University \\ Lampung, Indonesia \\ melindaputriaryanti@gmail.com
}

\author{
Khairunnisa Simbolon \\ International Relations Department \\ Lampung University \\ Lampung, Indonesia \\ khairunnisa.simbolon@fisip.unila.ac.id
}

\begin{abstract}
The Indonesian Government's decision to remove Fly Ash and Bottom Ash (FABA) coal waste from the hazardous and toxic materials (B3) list has generated pros and cons in various circles. The waste that comes from burning coal is known to have harmful side effects for health and damage to the environment and the living biota in it. However, according to the test results of the Indonesian Ministry of Environment, FABA waste does not meet the characteristics of $B 3$, and it has high economic benefits in several countries that have succeeded in managing this type of waste, such as China, Japan, the United States and others. If the Government can create good regulations, this waste will be a vast potential, both environmentally and economically. Learning from European countries that have succeeded in managing this waste by forming a particular association that deals with coal waste, Indonesia needs to apply international standards so that this potential does not impact environmental health through related international cooperation. Using the literature study method, this research will be qualitative, and environmental theory and international cooperation will describe and analyze Indonesia's opportunities in accelerating the use of FABA-type coal waste through international cooperation. The target achievement of this research is a policy recommendation for the Government on issues related to the handling of coal waste types of FABA.
\end{abstract}

Keywords-Coal Waste, Fly Ash and Bottom Ash, Environmental, International Cooperation.

\section{INTRODUCTION}

On March 12, the Indonesian Government officially removed Fly Ash and Bottom Ash (FABA) coal waste from the list of hazardous and toxic materials (B3). This decision immediately reaped the pros and cons because it has long been known that the ash from burning coal has terrible side effects for health. Whereas according to the test results of the Indonesian Ministry of Environment, FABA waste does not meet the characteristics of B3 [1] even FABA waste has many functions, such as a mixture of asphalt, cement, bricks, for agricultural needs (ECOBA General). FABA is ash or residue produced from burning coal in steam power plants (PLTU) or other coal-fueled industries. With a large number of PLTUs and industries that use coal as the primary energy material, inevitably,

Indonesia's FABA potential is also very high [2]. Several countries have succeeded in treating FABA waste and removing it from the B3 list, such as China, Japan, the United States, Australia, and many other European countries.

Elimination of FABA waste from the B3 list will increase the potential for FABA waste and reduce control over the treatment of that waste. If the Government removes FABA waste from the B3 list, it should be balanced with the management and processing of FABA waste not to accumulate and instead damage the environment and threaten public health. According to the Indonesian Coal Mining Association (APBI), Hendra Sinadia, Indonesia, produces at least 10-15 tons of FABA waste annually [3]. The Indonesian Agency for Research and Development of Energy and Mineral Resources (Litbang ESDM) also projects that by 2027 Indonesia will have 162 million tons of FABA waste. Indonesia, which is still new in processing FABA waste, does not yet have qualified technology and knowledge because so far, the use of FABA waste has only been in the form of scientific studies.

Indonesia certainly has to quickly adapt to this condition because otherwise, it will cause environmental problems. In order to accelerate the utilization of FABA waste, it is better if Indonesia has cooperation with other international actors. International cooperation is likely to increase the use of FABA waste, as is the case in Europe. Since 1990, European countries have created a particular association to handle coal waste - including FABA 
waste-the European Coal Combustion Products Associations or what we will call hereafter Ecoba.

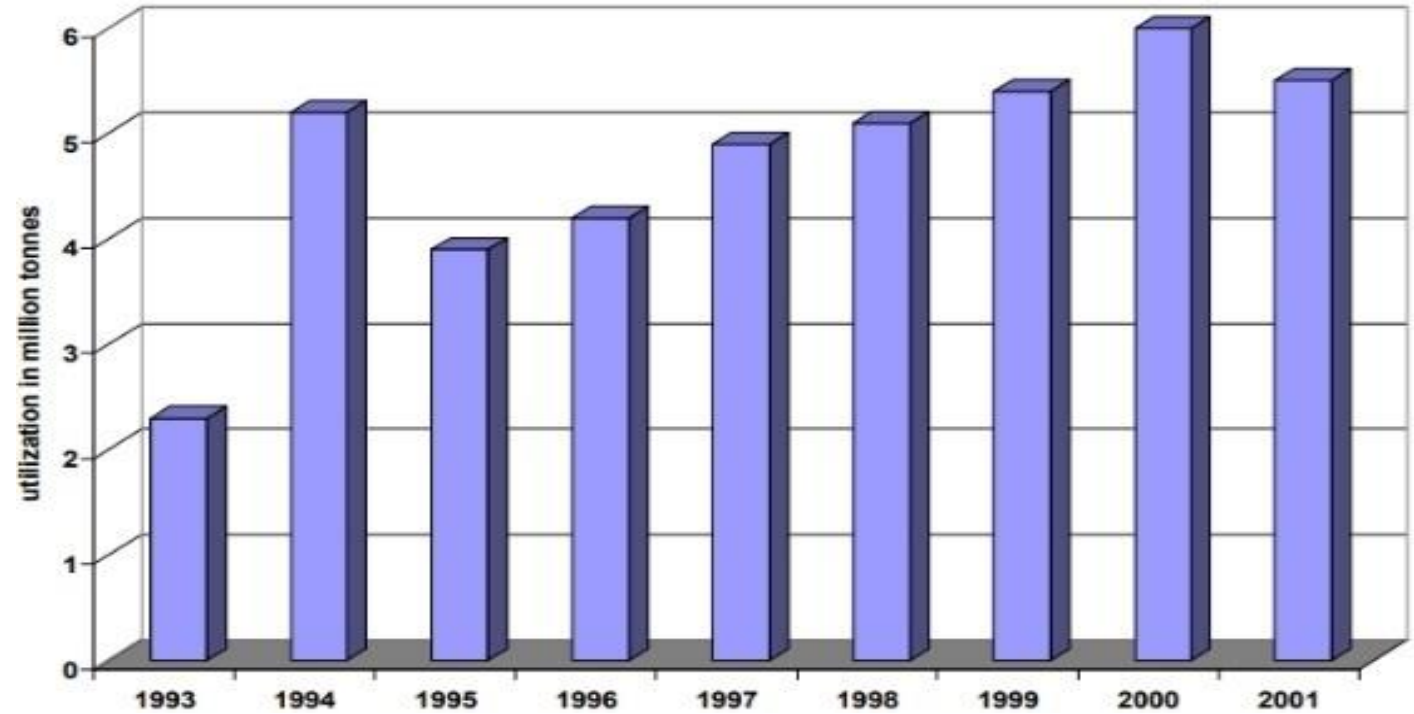

Fig. 1. Development of Fly Ash Utilization after Ecoba in 19932001.

The graph above shows an increase in the use of waste in a million tons. In 9 years, Ecoba member states have almost tripled their use. This increase occurred due to the disclosure of information, access to research, and policies between member countries. This openness and interconnectedness allow member countries to maximize the use of FABA waste. This condition is expected to occur in Indonesia in a short period, given the potential for FABA waste which is quite large, and it is feared that it will cause accumulation.

To carry out international cooperation, Indonesia needs first to map its potential and opportunities. There are at least two things that are considered by each international actor who cooperates; namely, each actor has a common goal, and there are benefits from the occurrence of such cooperation [4]. Based on this, Indonesia's potential and opportunities must fulfil these two elements to become a sound bargaining chip in international cooperation. By using analysis techniques of strength, weakness, opportunity and threat, researchers will analyze the potential of FABA waste in international cooperation.

\section{THEORITICAL FRAMEWORK}

\section{A. International Cooperation}

International Cooperation is a collaborative relationship between both countries and other actors to achieve specific goals through mutually agreed agreements. At the state level, International Cooperation occurs at the level of the central Government and external parties. Cooperation that occurs usually exists on industry standards and research (Informea). The collaboration makes actors adapt to existing conditions through policy coordination carried out by the actors involved [4]. For international

cooperation to occur, actors also consider the goals and benefits they get [4]. So, there are at least three things in International Cooperation: objectives, benefits, and policy coordination. In addition, actors in International Cooperation are not only countries with countries but can also be countries with IGOs, countries with INGOs, and other international actors.

In this study, the concept of International Cooperation is helpful for mapping cooperation opportunities for Indonesia. The mapping of opportunities is carried out based on two perspectives, namely Indonesia and other international actors. Thus, the results of the analysis will be obtained based on: 1) the goals of cooperation between Indonesia and other international actors; 2) the benefits that Indonesia and other international actors will get; 3 ) coordination of cooperation that Indonesia can carry out and other international actors, both at the industrial and scientific research levels.

\section{B. Global Environmental Politics}

Environmental issues are issues that are pretty difficult to describe in the world of politics. At first, environmental issues were considered not so important. Global attention to environmental issues goes hand in hand with the understanding that human activities impact the environment, such as the atmosphere, oceans, forests, soils, and a large number of animal and plant species. Environmental issues are also seen as a consequence of economic growth, population increase, increased human needs, changes in diet, and the phenomenon of urbanization [5]

Global Environmental Politics departs from the understanding that environmental issues cannot stand alone and cannot be seen from only one point of view. 
Environmental issues know no national borders because the resulting impacts can affect other countries directly, such as smoke, floods, weather and climate instability, and so on. Based on that, environmental activists at the international level are paying more attention to this issue. Pamlea Chasek describes the actors in environmental issues into seven actors, namely: ${ }^{[5]}$ 1) the state; 2) Intergovernmental Organizations (IGOs); 3) Treaty secretariat (more specific types of IGOs such as UNEP and UNDP); 4) International Financial Institutions; 5) Regional Organizations; 6) Nongovernmental Organizations (NGOs), and 7) Business/industry. The concept of Global Environmental Politics is helpful for this research to focus on the issues and international actors involved. Knowledge of the international actors involved will help map out opportunities for Indonesia to collaborate with these actors.

\section{RESEARCH METHODS}

This research is qualitative analytical research, which will use the data to conduct the analysis. The data used in this study were obtained from various sources, such as journals, books, official websites and statistical data published by the Government. This research was conducted by first identifying the actors who can play a role in International Cooperation based on Global Environmental Politics. The identification is focused only on the issue of FABA waste treatment. After completing the process, the actors who played a role in International Cooperation on FABA processing were analyzed using the SWOT (Strength, Weakness, Opportunity, and Threat) method. The analysis results will lead to conclusions regarding the most significant opportunity for Indonesia to collaborate with international actors on FABA waste treatment.

\section{RESULTS AND DISCUSSION}

\section{A. Indonesia Opportunities and Potential of FABA in Indonesia}

The importance of FABA processing in Indonesia should be undeniable. The use of FABA in Asia is relatively high, but Indonesia is still very far behind other countries. Even though Indonesia is a large coal supplier [6]. The prediction of the use of coal for electricity generation in Indonesia is very high in the next five years. Even in 2025, it is predicted to exceed other power plants. This means that the FABA type of coal waste produced will also be higher. So far, the FABA produced is only used for landfills. FABA handling that is not handled correctly has the potential to pollute the environment. Before FABA was removed from the $\mathrm{B} 3$ category, FABA was only allowed to settle and not be utilized, even though it has high economic potential, because it is still classified as hazardous waste. Therefore, the abolition of FABA from the B3 category is an opportunity for business actors in this field to take advantage of FABA economically.

FABA in Indonesia has begun to be used in several areas. Some preparations from FABA such as block and cement cast additives. FABA can also be used for ceramic materials and essential materials for house construction, concrete raw materials and river stone substitution. So far, the use of FABA is still minimal on a small scale and has not been used massively. Again this is because FABA was formerly classified as hazardous waste.

Indonesia is a country with very high use of coal (the primary source of FABA). According to the Ministry of Energy and Mineral Resources, domestic coal consumption in 2020 reached 108.45 tons, $69.97 \%$ of the domestic consumption target set by the Government, which was 155 million tons [7]. If PLN continues to use coal as the primary material for power plants, FABA production will remain high. According to the Balitbang of the Ministry of Energy and Mineral Resources, until now, PLN still relies on most of its energy from coal-fired power plants [8].

FABA is currently widely used as a substitute material in construction, such as roads and buildings. Research has shown that FABA can also be used as a raw material for making refractory casts and is used as a stockpile in mine reclamation. In addition, it can also be used as a land improvement material to improve physical soil conditions and planting media for revegetation of ex-mining land. According to several other studies and has been used abroad, FABA can also be used in agricultural activities, to improve the environment for plant growth, as a raw material for silica fertilizer, and as a material to prevent the formation of acid mine drainage [9].

The high potential of FABA in Indonesia, unfortunately, has not been utilized for maximum economic benefit. This is caused by many factors, including the volume of waste, quality and location. For volume, the amount of FABA that has been utilized is still low at around $45 \%$. The quality of FABA is also still varied and fluctuates not the same overall, which will undoubtedly affect the process when utilized. In addition, in the case of Indonesia, which is geographically broad, where the location of PLTU is usually remote, this impacts expensive management costs and shrinking economic value. 


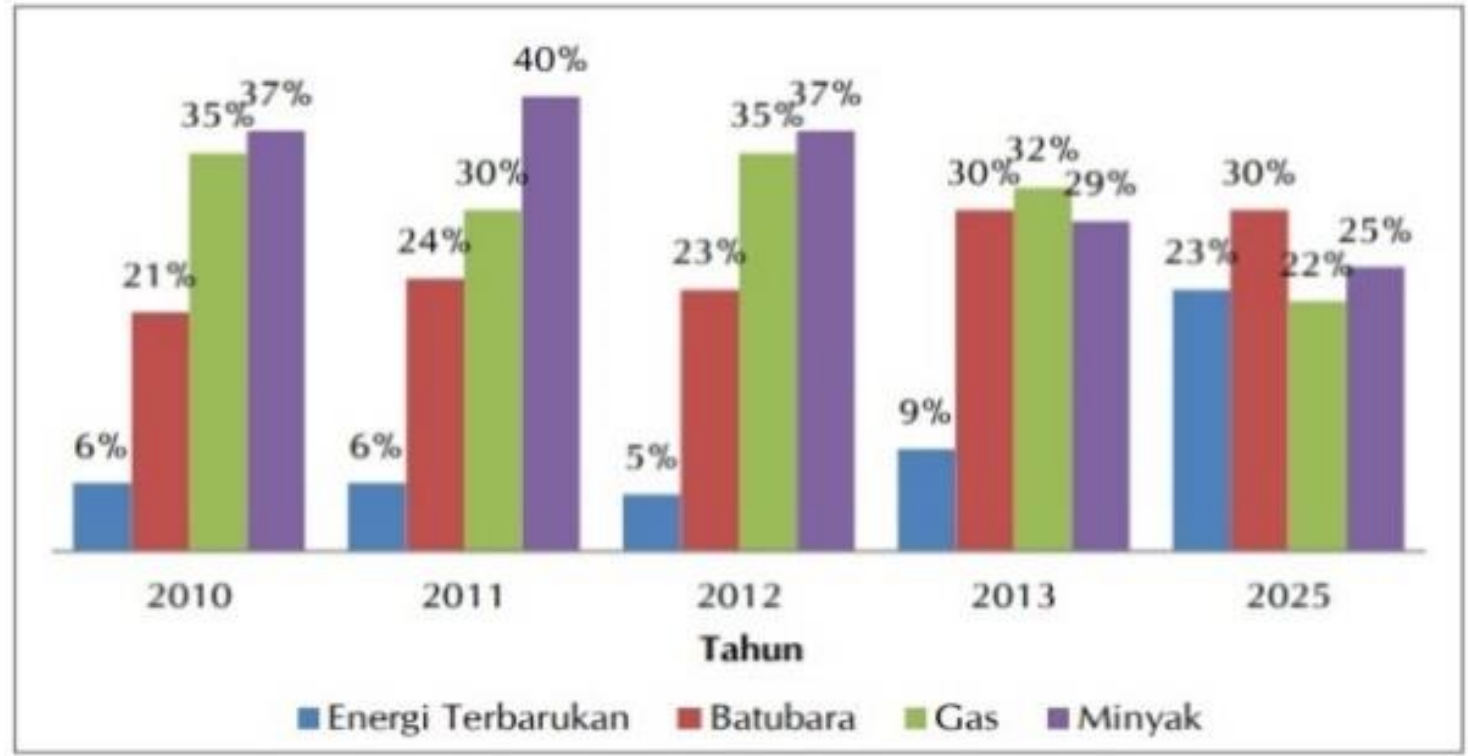

Fig. 2. Energy scenario for power generation [8].

\section{B. Increasing FABA Potential through International Cooperation}

Indonesia has several potentials if it wants to collaborate with other international actors in processing FABA waste. First is the elimination of FABA waste from the list of Toxic and Hazardous Materials (B3). Although this policy is controversial, the disposal of FABA waste from the B3 list will no longer require a permit from the Ministry of Environment and Forestry (KLHK), although the management planning is still monitored through Environmental Impact Analysis (AMDAL) (CNN, 2021). This means that this policy will cut the bureaucratic flow convoluted in utilising FABA waste later. Trimming the convoluted flow will be beneficial for anyone who wants to utilize FABA waste because it will make it easier for business actors engaged in the utilization of FABA.

However, recently the Minister of Environment and Forestry, Siti Nurbaya, revealed a plan to reduce coal use by $60 \%$ by 2050 [10]. If this is correctly done, it is feared that it will impact the continuity of cooperation in FABA waste treatment. Especially if Indonesia later has the intention to export commodities resulting from FABA waste processing. The decrease in coal use will undoubtedly have a good impact on the environment, but this will reduce FABA production. The Government needs to have long-term strategic steps in this regard. Second, the majority of countries in Southeast Asia have started research on FABA waste. Even Vietnam has removed FABA from the B3 list. This country has also started research on the use of FABA as a mixture of building materials since the 1990s [11].

Further from Vietnam, Laos started researching and processing Fly Ash in the 1970s or about 50 years ago [12]. Meanwhile, other Southeast Asian countries that have started research on FABA processing are Singapore, Vietnam, Thailand, Myanmar, the Philippines and Cambodia. However, especially for Cambodia, problems regarding the environment due to FABA have recently resurfaced, namely in the form of problems with the location where the FABA processing plant was built, which led to demands for relocation from the community [13]. The average use and management of FABA waste are bricks, cement, concrete and other building materials. Meanwhile, in Malaysia and Brunei Darussalam, the utilization and management of FABA are still very limited, while in Timor Leste, there is no sufficient accurate data on FABA waste treatment. 


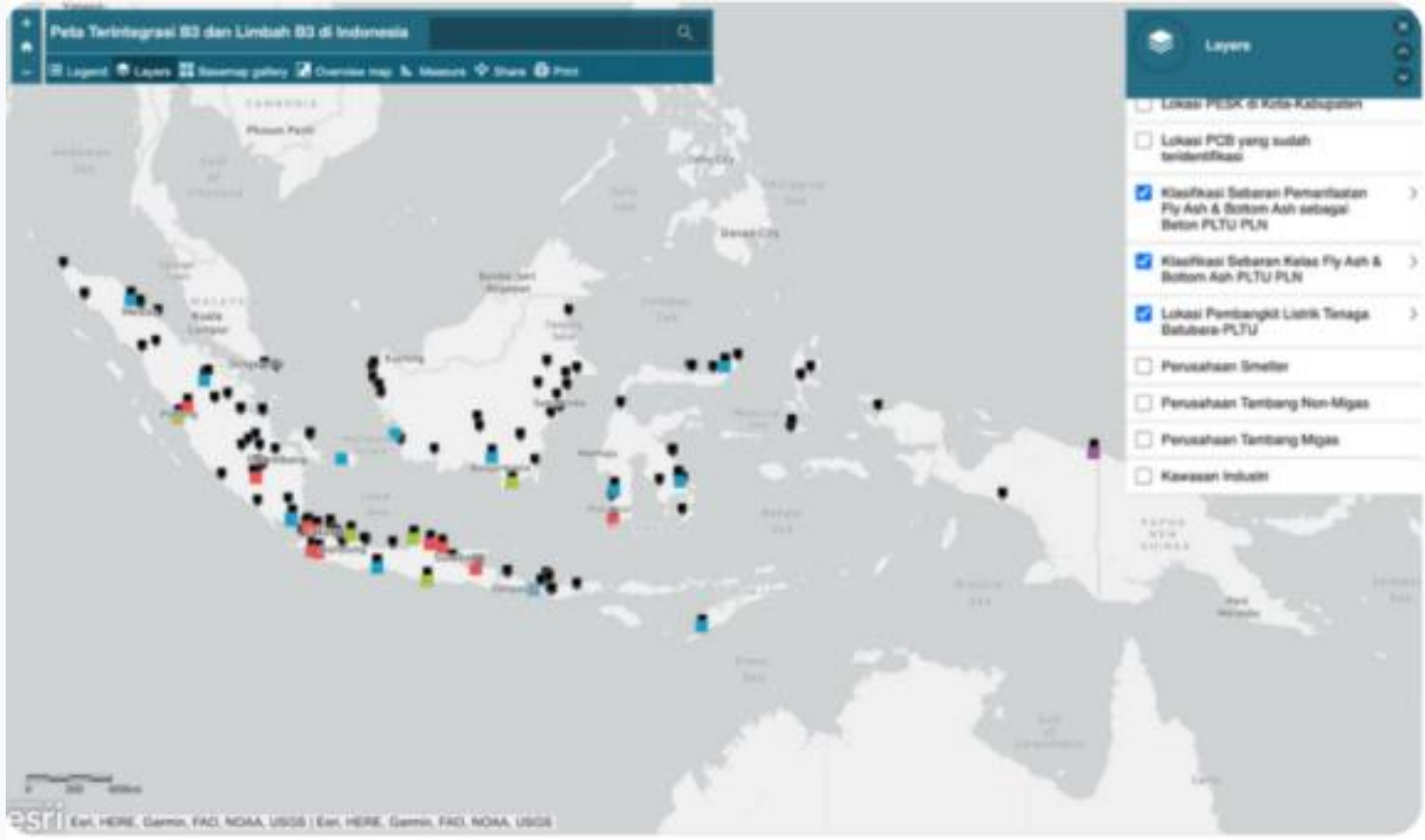

Fig. 3. PLTU distribution locations

Outside of the Southeast Asia region, Asian countries using FABA waste are Japan, China, South Korea and India. South Korea has utilized $89 \%$ of FABA waste. Then Japan, although categorizing FABA as a hazardous material, the Japanese Government allowed the processing of FABA. In 2011, Japan claimed that it had utilized $97 \%$ of coal waste [14]. In 2016, Indonesia planned to collaborate on joint FABA processing through the Japan Coal Energy Center (JCOAL). However, the cooperation did not seem to be going well because there was no continuation of the discourse. Then China claims to have utilized FABA up to $100 \%$, and India by $67 \%$ [15]. Indonesia already has a history of cooperation and has good diplomatic relations with countries that have used FABA, so exploring cooperation in waste utilization can also be carried out. For example, it could be by utilizing the transfer of technology and human resources. Transfer of technology and human resources is common in the use of technology.

Third, in the Southeast Asian region, a regional organisation oversees the ten Southeast Asian countries, namely ASEAN. Indonesia, which is a member of ASEAN, should benefit from this. The majority of ASEAN countries have conducted research and developed FABA management. There are at least two program areas in the ASEAN program under the ASEAN Plan of Action on Energy Cooperation (APAEC), namely the Area Program NO. Three concerning Coal and Program Area No. 6 regarding Regional Energy Outlook, Energy Policy and
Environmental Analysis. In Program Area No. 3, points 3.5 assist the impact of coal with the following description:

"Particularly, in the case of small-scale coal projects the entrepreneurs need external assistance on environmental impact assessments. The ASEAN mechanisms should be made available to carry out this purpose. ACE and/or AFOC should be endowed with funds, or expert capabilities to provide this

$$
\text { service" [16]. }
$$

While in Program Area No. 6, point 6.4 discusses reducing the environmental impact of energy use and mentions another ASEAN part that is more specific in discussing energy and its impacts and policies, namely the ASEAN Center for Energy (ACE) and its collaboration with the Energy Information Administration (EIA) of the United States.

"The actions required above will be undertaken by ACE utilizing its Homepage for information networking. An environmental specialist stationed at the ACE Headquarters shall be made available for this project and for providing assistance in EIA" [17].

The two quotes above show that ASEAN already has a forum to discuss the environmental impact of energy use, including coal and its waste. The inclusion of this issue into ASEAN should make it easier for Indonesia - and other Southeast Asian countries - to cooperate in the utilization of FABA waste to reduce environmental impacts. 


\begin{tabular}{|c|c|}
\hline $\begin{array}{l}\text { STRENGTH } \\
\text { 1. FABA removal from } \\
\text { B3 list } \\
\text { 2. Ease of bureaucratic } \\
\text { flow } \\
\text { 3. High pontential of } \\
\text { FABA production }\end{array}$ & \begin{tabular}{l}
\multicolumn{1}{c}{ WEAKNESS } \\
1. No special regulation \\
on FABA processing \\
2. Discourse on \\
reducing coal use by \\
2050
\end{tabular} \\
\hline \begin{tabular}{l}
\multicolumn{1}{c}{ THREAT } \\
1. No special regulation \\
at the regional level \\
on FABA processing \\
2. Not all Southeast Asia \\
countries utilize \\
FABA
\end{tabular} & $\begin{array}{l}\text { OPPORTUNITIES } \\
\text { 1. Southeast Asia } \\
\text { countries are } \\
\text { interconnected } \\
\text { through ASEAN } \\
\text { 2. ASEAN has special } \\
\text { program for } \\
\text { environment and } \\
\text { coal processing } \\
\text { 3h. Majority of } \\
\text { Southeast Asian } \\
\text { countries have } \\
\text { strated research on } \\
\text { FABA processing }\end{array}$ \\
\hline
\end{tabular}

Fig. 4. SWOT Table

Meanwhile, opportunities to collaborate with other actors, such as NGOs, MNCs, and International Financial Institutions, tend to be smaller. There are no NGOs, MNCs, or International Financial Institutions in the Southeast Asia region that pay more attention to FABA waste treatment. They focus more on conservation culture, smoke waste, weather and climate change, and water and soil sustainability. The closest issue is attention to coal mining and processing, but for FABA, it is still infrequent. One of the NGOs in Asia (covering Southeast Asia) that is engaged in environmental issues is the Asia Environmental Foundation. Meanwhile, there are no MNCs and International Financial Institutions in Southeast Asia that focus, or at least pay more attention to FABA waste treatment.

We can see that countries in the Southeast Asian region - although not all - have started to cultivate FABA. However, the research and processing steps tend to be carried out alone without good cooperation in FABA waste treatment. This means that there is no specific regulation that regulates the processing of FABA waste. In addition, the majority of Southeast Asian countries are doing research, so that the most likely collaboration soon is in terms of research and the transfer of experts.

Even so, ASEAN, as the largest Southeast Asian regional organization, actually aims to renew energy use, waste, and the environment. This means, even though Indonesia has difficulty initiating cooperation at the inter-country level, this cooperation can be done by intensifying ASEAN's role in utilising FABA waste through its programs. However, based on Area Program No. 3, ASEAN also still needs funding and experts. In addition, Indonesia's plan to reduce coal use by up to $60 \%$ by 2050 needs to be studied more seriously if Indonesia wants to use FABA waste sustainably.

\section{CONCLUSION}

Elimination of FABA from B3 waste is the Government's first step in utilising coal waste or FABA. The high use of domestic coal, such as in steam power plants, and factories that still use coal as fuel, can increase the economic potential of waste. FABA can be used for many fields such as building and road construction, the substitution of some materials, and agriculture. Such great potential needs careful planning from the Government to be processed optimally and bring economic benefits as expected.

Many countries have been using FABA waste for a long time in various fields. Indonesia can learn from these countries through international cooperation. International cooperation at various levels needs to be explored by the Indonesian Government so that the potential of FABA is optimal. At the regional level, ASEAN cooperation can be used as the first step in carrying out cooperation with member countries, apart from the fact that it already has a cooperation framework that has been prepared in the ASEAN Plan of Action on Energy Cooperation. Indonesia has many countries to cooperate with at the bilateral level, such as Japan, South Korea, China, and others.

The challenge of FABA utilization found in this study is the lack of domestic FABA utilization. This is due to the limited field that utilizes the use of FABA. Previously, regulatory issues categorizing FABA as B3 were also an obstacle to its utilization. The factors of production costs and the quality of the waste produced are also inhibiting factors that must be found a solution. Technology and research on FABA also need to be improved. One way is the transfer of technology and resources. This can be implemented through international cooperation by including specific clauses in the cooperation agreement. FABA's economic potential will provide a significant income for the 
country. However, further studies are needed on how to make the most of it.

\section{REFERENCES}

[1] KLHK Tetap Awasi Limbah Batu Bara Meski Kini Tak Perlu Izin. (2021, Maret 16) diakses pada 1 Maret 2021 melalui https://www.cnnindonesia.com/nasional/2021031516240420-617699/klhk-tetap-awasi-limbah-batu-bara-meski-kinitak-perlu-izin

[2] Bisnis News (2021). Tinggi, Potensi Dan Pemanfaatan Faba Di Indonesia https://bisnisnews.id/detail/berita/tinggipotensi-dan-pemanfaatan-faba-di-indonesia

[3] Novika, Soraya. (2021). Fakta-fakta Abu Batu Bara Dihapus dari Daftar Limbah Berbahaya. https://finance.detik.com/energi/d-5491653/fakta-fakta-abubatu-bara-dihapus-dari-daftar-limbah-berbahaya

[4] Helen, Milner (1992). International Theori es of Cooperation Among Nations: Strengths and Weaknesses. World Politics, 44, pp 466-496 doi:10.2307/2010546

[5] Chasek, Pamela S, dkk. (2018). Global Environmental Politics 7th Edition. Routledge: New York. Hlm. 11.

[6] Pemanfaatan FABA di Indonesia Tertinggal Jauh Dibanding Negara Lain. (2021, April) diakses melalui https://www.liputan6.com/bisnis/read/4521511/pemanfaatanfaba-di-indonesia-tertinggal-jauh-dibanding-negara-lain pada 26 Juni 2021

[7] CNBC (2020) Konsumsi Batu Bara Domestik Akhirnya Tembus $100 \quad$ Juta $1 / 1172915-4-$ 201133/konsumsi-batu-bara-domestik-akhirnya-tembus-100juta-ton

[8] Damayanti, Retno. (2018). Abu Batu Bara dan Pemanfaatannya: Tinjauan Teknis Karakteristik Secara Kimia dan Toksologinya. Jurnal Teknologi Mineral dan Batubara. Vol 14, Nomor 3. Puslitbang Teknologi Mineral dan Batubara: Bandung.
[9] Kementrian Lingkungan Hidup dan Kehutanan Republik Indonesia. (2021). Fly Ash dan Bottom Ash (FABA) Hasil Pembakaran Batubara Wajib Dikelola. http://www.menlhk.go.id/site/single_post/3707/fly-ash-danbottom-ash-faba-hasil-pembakaran-batubara-wajib-dikelola

[10] Fey. (2021). Pemerintah Tekan Penggunaan Batu Bara 60 Persen di 2050. Diakses melalui Pemerintah Tekan Penggunaan Batu Bara 60 Persen di 2050 (cnnindonesia.com) pada 30 Mei 2021

[11] Manh Dau, Nguyenv \& Trinh Viete Cuong. (1993) Coal Ash in Vietnam: Deposition and Utilization. IBST: Hanoi. Page 49-61.

[12] About Fly Ash. Diakses pada 1 Maret 2021 melalui http://www.laoholding.com/About_Fly_Ash.aspx

[13] Environment Ministry Orders Relocation of a Coal Ash Processing Company Due to Health Impacts. (2021, Maret 2) diakses pada 1 Juni 2021 melalui https://cambodianess.com/article/environment-ministryorders-relocation-of-a-coal-ash-processing-company-due-tohealth-impacts

[14] Manan, Abdul. (2021). Processing Coal the Asian Way. Jakarta: Tempo. Diakses melalui https://magz.tempo.co/read/37998/processing-coal-the-asianway

[15] Prasetiawan, Teddy. (2021). Kontroversi Penghapusan FABA dari Daftar Limbah B3. Info Singkat: Kajian Singkat Terhadap Isu Aktual dan Strategis. Vol XIII No 7. Pusat Penelitian DPR RI: Jakarta.

[16] ASEAN. Program Area No. 3: Coal. Diakses melalui https://asean.org/?static_post=programme-area-no-3-coal pada 2 Juni 2021.

[17] ASEAN. PROGRAMME AREA NO. 6: Regional Energy Outlook, Energy Policy and Environmental Analysis. Diakses melalui https://asean.org/?static_post=programmearea-no-6-regional-energy-outlook-energy-policy-andenvironmental-analysis pada 2 Juni 2021. 